\title{
Estrogen-dependent up-regulation of TRPA1 and TRPV1 receptor proteins in the rat endometrium
}

\author{
Krisztina Pohóczky ${ }^{1,2}$, József Kun ${ }^{1,2,6}$, Bálint Szalontai ${ }^{2}$, Éva Szőke ${ }^{1,2,6}$, Éva Sághy ${ }^{1,2}$, \\ Maja Payrits ${ }^{1,2}$, Béla Kajtár ${ }^{3}$, Krisztina Kovács ${ }^{3}$, József László Környei ${ }^{4}$, János Garai ${ }^{5}$, \\ András Garami ${ }^{5}$, Anikó Perkecz ${ }^{1}$, Levente Czeglédi ${ }^{7}$ and Zsuzsanna Helyes 1,2,6 \\ ${ }^{1}$ Department of Pharmacology and Pharmacotherapy, University of Pécs Medical School, Szigeti Street 12, \\ H-7624 Pécs, Hungary \\ ${ }^{2}$ Janos Szentagothai Research Centre, University of Pécs, Ifjúság Street 20, H-7624 Pécs, Hungary \\ ${ }^{3}$ Departments of Pathology, University of Pécs Medical School, Szigeti Street 12, H-7624 Pécs, Hungary \\ ${ }^{4}$ Department of Physiology, University of Pécs Medical School, Szigeti Street 12, H-7624 Pécs, Hungary \\ ${ }^{5}$ Department of Pathophysiology and Gerontology, University of Pécs Medical School, Szigeti Street 12, \\ H-7624 Pécs, Hungary \\ ${ }^{6}$ MTA-PTE NAP B Chronic Pain Research Group, Hungary, Szigeti Street 12, H-7624 Pécs, Hungary \\ ${ }^{7}$ Institute of Animal Science, Centre for Agricultural and Applied Economic Sciences, University of Debrecen, \\ PO Box 36, H-4015 Debrecen, Hungary
}

Correspondence

should be addressed

to Zs Helyes

Email

zsuzsanna.helyes@aok.pte.hu

\begin{abstract}
Transient receptor potential ankyrin 1 (TRPA1) and vanilloid 1 (TRPV1) receptors expressed predominantly in sensory nerves are activated by inflammatory stimuli and mediate inflammation and pain. Although they have been shown in the human endometrium, their regulation and function are unknown. Therefore, we investigated their estrogen- and progesterone-dependent alterations in the rat endometrium in comparison with the estrogenregulated inflammatory cytokine macrophage migration inhibitory factor (MIF). Four-week-old (sexually immature) and four-month-old (sexually mature) female rats were treated with the non-selective estrogen receptor (ER) agonist diethylstilboestrol (DES), progesterone and their combination, or ovariectomized. RT-PCR and immunohistochemistry were performed to determine mRNA and protein expression levels respectively. Channel function was investigated with ratiometric $\left[\mathrm{Ca}^{2+}\right]_{i}$ measurement in cultured primary rat endometrial cells. Both TRP receptors and MIF were detected in the endometrium at mRNA and protein levels, and their localizations were similar. Immunostaining was observed in the immature epithelium, while stromal, glandular and epithelial positivity were observed in adults. Functionally active TRP receptor proteins were shown in endometrial cells by activation-induced calcium influx. In adults, Trpa1 and Trpv1 mRNA levels were significantly up-regulated after DES treatment. TRPA1 increased after every treatment, but TRPV1 remained unchanged following the combined treatment and ovariectomy. In immature rats, DES treatment resulted in increased mRNA expression of both channels and elevated TRPV1 immunopositivity. MIF expression changed in parallel with TRPA1/TRPV1 in most cases. DES up-regulated Trpa1, Trpv1 and Mif mRNA levels in endometrial cell cultures, but 17 $\beta$-oestradiol having ER $\alpha$-selective potency increased only the expression of Trpv1. We provide the first evidence for TRPA1/TRPV1 expression and their estrogen-induced up-regulation in the rat endometrium in correlation with the MIF.
\end{abstract}

\footnotetext{
Keywords

- transient receptor potential ankyrin 1 and vanilloid 1

- macrophage migration inhibitory factor

- rat endometrium

- estrogen

- progesterone

- mRNA expression

- immunohistochemistry

- fluorescent calcium imaging
}

Journal of Molecular
Endocrinology

(2016) 56, 135-149
(C) 2016 Society for Endocrinology Printed in Great Britain
Published by Bioscientifica Ltd 


\section{Introduction}

Transient receptor potential ankyrin 1 (TRPA1) and vanilloid 1 (TRPV1) are non-selective cation channels predominantly localized in capsaicin-sensitive peptidergic sensory neurons and mediate pain and inflammation (Szallasi et al. 2007). TRPV1 or 'capsaicin receptor' is activated by noxious heat $\left(>43{ }^{\circ} \mathrm{C}\right)$, protons $(\mathrm{pH}>5.5)$, bradykinin, lipoxygenase products and anandamide produced during inflammation and tissue injury. TRPV1 is also expressed in the CNS (Szolcsanyi 1988, Mezey et al. 2000) and in several non-neuronal cells in the skin, kidneys, lungs, testis, pancreas, spleen, cornea and uterus (Rocha et al. 2011, Liu et al. 2012, Song et al. 2012). Although the physiological/pathophysiological relevance of nonneuronal TRP is unknown, a cross-talk has been proposed between non-neuronal and neuronal TRP channels (Denda et al. 2010, Assas et al. 2014). Activation of non-neuronal TRPV1 in various cells results in mediator release with both physiological and pathological functions (Fernandes et al. 2012): activation of epidermal TRPV1 increases IL8 and prostaglandin $\mathrm{E}_{2}$ (Southall et al. 2003), while TRPA1 induces IL1A and IL1B release (Nilius \& Szallasi 2014).

TRPA1 is also activated by various chemical and physical stimuli, such as noxious cold $\left(<17^{\circ} \mathrm{C}\right)$, allyl-isothiocyanate and cinnamaldehyde, as well as endogenous ligands including hydrogen peroxide, formaldehyde, methylglyoxal and acrolein produced during inflammation and tissue damage (Nagata 2007). The pathophysiological relevance of TRPA1 has been shown in inflammatory diseases of the respiratory, cardiovascular and gastrointestinal tracts. Similarly to TRPV1, functional TRPA1 was also described in enterochromaffin cells, synoviocytes, fibroblasts, melanocytes, pancreatic $\beta$-cells, epidermal keratinocytes, intestinal epithelial cells and macrophages, as well as human endometrial cells besides sensory neurones (Fernandes et al. 2012, Greaves et al. 2014).

Macrophage migration inhibitory factor (MIF) was originally identified as a T-cell-derived lymphokine (David 1966); it regulates immune responses and pain, but its specific receptor has not yet been identified. It is constitutively expressed by macrophages and $\mathrm{T}$ cells (Nishihira 2000), neurons (Bacher et al. 1998), vascular endothelial cells and smooth muscle cells (Lin et al. 2000). A hormonal cycle-dependent expression of MIF was described in the human endometrium, which was elevated during the late proliferative and early secretory phases predominantly driven by estrogen (Yang et al. 2000, Kats et al. 2005, Akoum et al. 2006). MIF is also involved in human ectopic endometrial cell proliferation (Yang et al.
2000), and has been proposed a biomarker of endometriosis (Akoum et al. 2006). The two estrogen receptor (ER) subtypes $E R \alpha$ and $E R \beta$ respond similarly to some ligands, but there are also several receptor-specific activators and responses. These receptors are located in the nucleus and regulate the transcription of specific target genes by binding to associated DNA regulatory sequences. In the uterus, $\mathrm{ER} \alpha$ is present similarly to the mammary gland, ovary and bone. By contrast, ER $\beta$ is found mainly in the prostate, bladder, ovary, colon, adipose tissue and the immune system. Both subtypes are markedly expressed in the cardiovascular and CNSs (Paterni et al. 2014). The synthetic compound diethylstilboestrol (DES) is a non-selective agonist, while $17 \beta$-oestradiol has an ER $\alpha$-selective agonist potency (Barkhem et al. 1998).

TRP channels have recently been described in the human endometrium, accompanied with estrogen/progesterone-induced decidualization, where the TRP canonical 1 (TRPC1) channel has been shown to be up-regulated in vitro (Kumar et al. 2014). A member of the TRPV subfamily, TRPV6, is also present in the luminal and glandular epithelia of the human, rat, mouse and pig endometrium. TRPV6 has a cycle-dependent expression pattern in the mouse and human endometrium, and the maximal amount of Trpv6 mRNA was detected during the proliferative phase, or oestrus in the presence of high estrogen levels (Kumar et al. 2014).

Although TRPV1 and TRPA1 have been shown in the human eutopic and ectopic endometrium, their regulation and functional importance are not known (Wu et al. 2010, Liu et al. 2012, Song et al. 2012). Furthermore, there are no data regarding the link between ER activation and the expression of TRP channels and MIF in the normal endometrium related to different hormone levels. Animal models are important to precisely investigate their alterations during sexual maturation, the influence of estrogen/gestagen actions and ER-dependent mechanisms. Therefore, we aimed to describe the expression of TRPV1 and TRPA1 in the rat endometrium at mRNA and protein levels, as well as their hormonedependent changes in correlation with the MIF.

\section{Materials and methods}

\section{Ethics}

All experimental procedures were carried out according to the 1998/XXVIII Act of the Hungarian Parliament on

Published by Bioscientifica Ltd 
Animal Protection and Consideration Decree of Scientific Procedures of Animal Experiments (243/1988) and complied with the recommendations of the International Association for the Study of Pain. All experiments were approved by the Ethics Committee on Animal Research of Pécs University according to the Ethical Codex of Animal Experiments (licence: BA02/2000-11/2011).

\section{Animals and treatments}

Four-week-old and four-month-old female Wistar rats were bred and kept in the Laboratory Animal House of the Department of Pharmacology and Pharmacotherapy, University of Pécs. They were kept with a ratio of $12 \mathrm{~h}$ light: $12 \mathrm{~h}$ darkness at $24-25^{\circ} \mathrm{C}$ and had access to food and water ad libitum. Rats of both ages were implanted with s.c. bee wax pellets containing the synthetic estrogen analogue DES (100 $\mu \mathrm{g}, \sim 2 \mu \mathrm{g}$ daily release), or were administered daily $2 \mathrm{mg}$ s.c. progesterone (Sigma-Aldrich) dissolved in sesame oil for three consecutive days ( $n=5$ /group) (Garai \& Clark 1992). When given in combination, progesterone administration started 2 days after DES pellet implantation. In a separate group of mature rats $(n=5)$, ovariectomy was performed in order to investigate the effect of reduced endogenous hormone production. Samples were taken 10 days after completing the treatments; solvent-treated/sham-operated animals of the same age were used as controls.

\section{Tissue preparation and analysis}

Animals were killed under deep anaesthesia (sodium thiopental, $50 \mathrm{mg} / \mathrm{kg}$ i.p.; Sandoz, Kundl, Austria) and the uterus horns were harvested. The endometrium was scraped from the myometrium: one part was placed in RNA-Later solution (Sigma-Aldrich) and stored at $-80^{\circ} \mathrm{C}$; the other one was fixed in $4 \%(\mathrm{v} / \mathrm{v})$ paraformaldehyde, embedded in paraffin and sectioned for immunohistochemical analysis.

\section{RNA extraction and quantitative real-time PCR}

Total RNA was extracted using TRI Reagent (Molecular Research Centre, Inc., Cincinnati, OH, USA) and the Direct-Zol RNA isolation kit, and then treated with DNase I (both supplied by Zymo Research, Irvine, CA, USA) to remove genomic DNA. RNA was measured with a NanoDrop ND-1000 Spectrophotometer (NanoDrop Technologies, Inc., Wilmington, DE, USA). First-strand cDNA synthesis was carried out with $1 \mu \mathrm{g}$ of total
RNA/sample using the RevertAid H Minus First Strand cDNA Synthesis Kit (Thermo Scientific, Waltham, MA, USA) with oligo(dT $)_{18}$ primers. Relative gene expression ratios were measured with Stratagene Mx3000P QPCR System (Agilent Technologies, Santa Clara, CA, USA), using peptidyl-prolyl cis-trans isomerase A (Ppia) as the reference gene. Each reaction contained $2 \mu \mathrm{l}$ of cDNA, $10 \mu \mathrm{l}$ Luminaris Color HiGreen Low ROX qPCR Master Mix (Thermo Scientific), $0.3 \mu \mathrm{M}$ primer and $6.8 \mu \mathrm{l}$ water. The following primer pairs were used to amplify the target loci: Trpa1 (sense): 5-AGTGGCAATGTGGAGCGATA-3 and (antisense): 5-TC CCGTCGATCTCAGCAATG-3; Trpv1 (sense): 5-AATAC ACCATCGCTCTGCT-3 and (antisense): 5-CAATGTGCA GTGCTGTCTGG-3; Mif (sense): 5-CACCATGCCTA TGTTCATCGTGAACA-3 and (antisense): 5-GCCCGGG CTCAAGCGAAGGTGGAACCGGTT-3 (Sun et al. 2005); inducible nitric oxide synthase (iNOS (Nos2)) (sense): 5-CCAAGATGGCCTGGAGGAAC-3 and (antisense): 5-TGATGCAGTGCTACAGCTCC-3; interleukin 1 beta (Illb) (sense): 5-CCTATGTCTTGCCCGTGGAG-3 and (antisense): 5-CATCCCACGAGTCACAGAGG-3; Ppia (sense): 5-GCAGACAAAGTTCCAAAGACAG-3 and (antisense): 5-CCATTATGGCGTGTGAAGTC-3. Amplification was carried out under the following conditions: $95^{\circ} \mathrm{C}$ (10 min), followed by 40 cycles of $95^{\circ} \mathrm{C}(15 \mathrm{~s}), 60^{\circ} \mathrm{C}(45 \mathrm{~s})$ and $72{ }^{\circ} \mathrm{C}(45 \mathrm{~s})$. Measurements included a dissociation curve analysis to verify amplification specificity. Reactions were carried out in triplicate; relative expression ratios were calculated using MxPro QPCR Software (Agilent Technologies) with $\Delta \Delta C$ t method, using samples of untreated animals as a calibrator. Primer efficiencies were taken into account when calculating gene expression ratios (Pfaffl 2001).

\section{Immunohistochemistry}

Paraformaldehyde-fixed, paraffin-embedded samples were deparaffinized, rehydrated and incubated in acidic citrate buffer ( $\mathrm{pH}$ 6) in a microwave oven for antigen recovery, and then treated with 3\% hydrogen peroxide to quench endogenous peroxidase activity. After washing, the sections were incubated in normal blocking solution and treated with rabbit polyclonal anti-TRPV1 (Neuromics, Edina, MN, USA), anti-TRPA1 (Abcam, Cambridge, UK) and anti-MIF (Life Technologies) antibodies at a 1:1000 dilution. Incubation was performed with the EnVision system anti-rabbit secondary antibody conjugated with HRP (DakoCytomation, Carpinteria, CA, USA) and the reaction was visualized using 3,3-diaminobenzidine tetrachloride containing $0.01 \%$ hydrogen peroxide

Published by Bioscientifica Ltd. 
(Kun et al. 2012). Histological counterstaining was performed with haematoxylin. Semi-quantitative scoring of TRPA1/TRPV1 and MIF immunopositivity was performed by an expert pathologist blinded to the study. Incubating untreated rat endometrial cells with Trisbuffered saline instead of the primary antibodies served as the negative control. Sections of rat trigeminal ganglia showing a high expression of TRPA1 and TRPV1 channels were used as positive controls. Representative images of each slide were captured with a research microscope system fitted with a digital camera (Olympus BX51). TRPA1, TRPV1 and MIF immunostaining intensity was evaluated by a semi-quantitative scoring system ranging from 0 to 3 ( 0 , no staining; 1 , weak staining in the majority of cells with only focal moderate staining; 2, moderate staining in the majority of cells with only focal strong staining; 3 , strong staining in the majority of cells). The selectivity of the antibodies was proven by the lack of staining after the respective blocking peptide and literature data (Potolicchio et al. 2003) respectively. The endometrial thickness was measured in five different sections of each animal and then averaged in all the experimental groups.

\section{Primary cultures of rat endometrial cells}

Primary endometrial cell cultures were prepared in order to test the functionality of TRPV1 and TRPA1 receptors by detecting agonist-evoked $\mathrm{Ca}^{2+}$ influx responses, as well as to determine their ER activation-induced expression regulations and correlation with the MIF. Four-week-old
Wistar rats were decapitated under ether anaesthesia. Uteri were placed and cut into small strips in sterile incomplete Hank's balanced salt solution (HBSS, $\mathrm{Ca}^{2+}$ and $\mathrm{Mg}^{2+}$ free, $\mathrm{pH}$ 7.4) containing $1 \mathrm{M}$ HEPES, $2 \%$ antibiotic-antimycotic solution and $1 \mathrm{M}$ sodium hydroxide. Samples were placed in $10 \mathrm{ml}$ HBSS containing $0.1 \%$ collagenase and $0.005 \%$ DNaseI and incubated at $37^{\circ}$ for $30 \mathrm{~min}$, and the dispersed cells were digested with $0.01 \%$ trypsin and $0.005 \%$ DNaseI at $37^{\circ}$ for $5 \mathrm{~min}$. Pellets were washed three times with HBSS and cultured in enriched DMEM (high glucose) containing $10 \%$ fetal bovine serum, $2 \%$ antibioticantimycotic solution and $0.004 \%$ kanamycin (Kornyei et al. 2001). All chemicals were purchased from SigmaAldrich. Cells were pre-incubated for $18 \mathrm{~h}$ with the physiological concentration of $200 \mathrm{pM} 17 \beta$-oestradiol (Herbison 2009) having relative selectivity to $\mathrm{ER} \alpha$, and the same concentration of the non-selective ER $\alpha$ and ER $\beta$ receptor agonist DES was used in our in vivo experiment (Barkhem et al. 1998).

After the calcium imaging measurements, cells were isolated from the plate by trypsin-EDTA diluted in incomplete HBSS, centrifuged at $700 \mathrm{~g}$ for $5 \mathrm{~min}$, and then the pellet was resuspended in $600 \mu \mathrm{l}$ RNA-Later solution (Sigma-Aldrich). Total RNA was isolated with TRI Reagent the same way as from the endometrial tissues. After DNase I digestion, the first-strand cDNA synthesis was performed from $5 \mathrm{ng}$ of total RNA using the High-Capacity cDNA Reverse Transcription Kit (Applied Biosystems).

To evaluate the effects of chronic DES pretreatment in our in vitro cell culture, test the functionality of the TRP
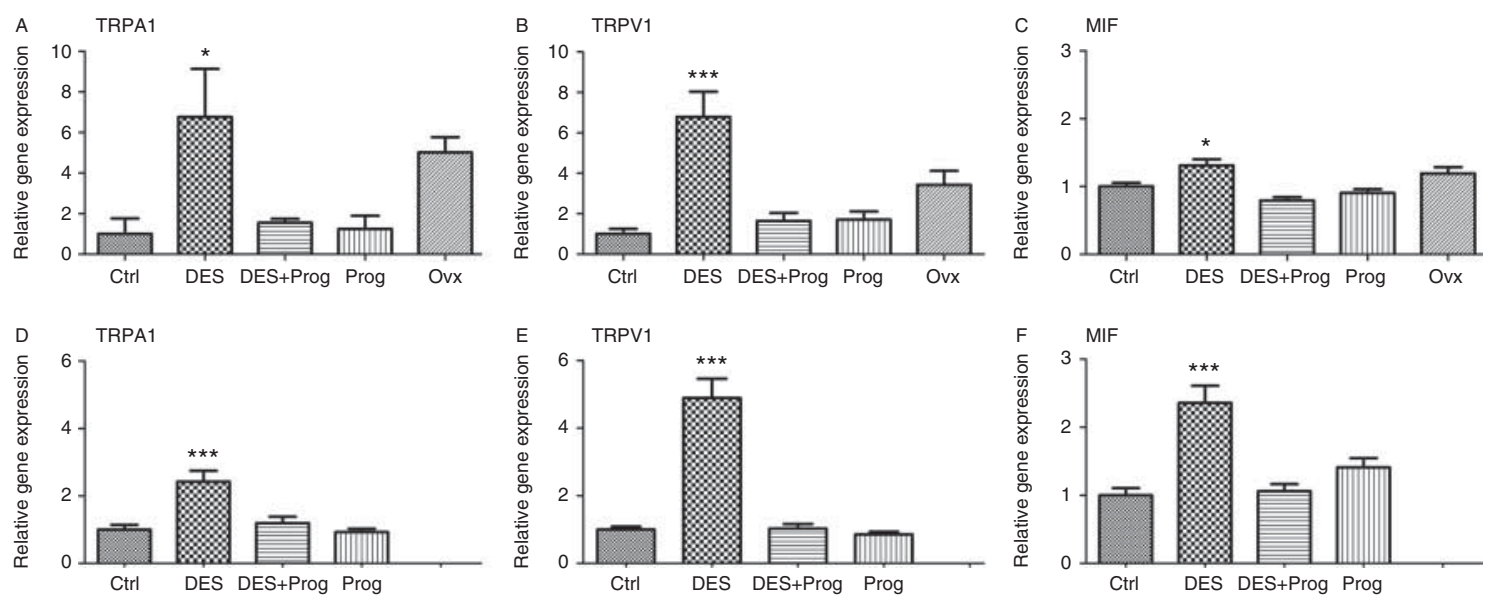

\section{Figure 1}

Relative gene expression of ( $A$ and $D)$ Trpa1 and ( $B$ and $E)$ Trpv1 receptors, as well as ( $C$ and F) Mif in the hormone-treated adult ( $\mathrm{A}, \mathrm{B}$ and $\mathrm{C}$ ) and young $(D, E$ and $F)$ rat endometrium $(n=5)$. Fold change represents respective mRNA levels normalized to Ppia as a housekeeping gene following the $\Delta \Delta C T$ method. Each column represents the ratio of relative gene expression (mean \pm S.E.M.; one-way ANOVA with Dunnett's multiple comparison test: $\left.{ }^{*} P<0.05, * * * P<0.0001\right)$. http://jme.endocrinology-journals.org DOI: 10.1530/JME-15-0184
(C) 2016 Society for Endocrinology Printed in Great Britain
Published by Bioscientifica Ltd 
receptors, and find a direct link between the MIF cytokine and TRPA1/TRPV1, we made primary endometrial cell cultures from DES-pretreated $(100 \mu \mathrm{g}, \mathrm{w} / \sim 2 \mu \mathrm{g}$ daily release) and placebo-pretreated 4-month-old rats for 10 days (bee wax pellet without active ingredient). Subconfluent phase of the cultured endometrial cells was treated for $24 \mathrm{~h}$ with $1 \mu \mathrm{g} \mathrm{MIF} / \mu \mathrm{l}, 330 \mathrm{nM}$ capsaicin and $3.3 \mathrm{mM}$ formalin respectively and the relative gene expression ratios of Trpa1, Trpv1, iNOS and $I l 1 b$ were measured by qPCR.

\section{Ratiometric technique of $\left[\mathrm{Ca}^{2+}\right]_{i}$ measurement}

Sub-confluent phase of the cultured endometrial cells was determined with phase-contrast microscopy on day 7 . Uterine cells were digested with trypsin and placed in lysine-covered 24-well plates before the intracellular calcium $\left(\left[\mathrm{Ca}^{2+}\right]_{\mathrm{i}}\right)$ measurement. Cultures were stained with the fluorescent $\mathrm{Ca}^{2+}$ indicator dye fura-2-AM, as described in detail previously (Szoke et al. 2010). $\left[\mathrm{Ca}^{2+}\right]_{\mathrm{i}}$ measurement was done in extracellular solution (ECS) by fluorescence microscopy: ECS and the test solutions were given via separate tubes and rapid solution changes were controlled by the fast-step perfusion system. Fluorescence images were taken after illuminating the cells alternately at 340 and $380 \mathrm{~nm}$ light generated by a monochromator. The emitted light $>510 \mathrm{~nm}$ was measured with Axon Imaging Workbench 2.1 (AIW) software. The fluorescence ratio F340/F380 was monitored (rate $1 \mathrm{~Hz}$ ) continuously for up to $5 \mathrm{~min}$ and $R$ values were generated by the AIW software. Baseline fluorescence was read from the period of recordings taken before exposing the cells to the TRPV1 agonist capsaicin $(330 \mathrm{nM})$ or the TRPA1 agonist formalin $(3.3 \mathrm{mM})$.

\section{Statistical analysis}

Values are expressed as mean \pm s.E.M. of $n=5 /$ group. For evaluating gene expression, analysis was performed by one-way ANOVA followed by Dunnett's multiple comparison test. For the analysis of the semi-quantitative scoring of the immunohistochemical results, the non-parametric Kruskal-Wallis test with Dunn's post-test was used. $P \leq 0.05$ was considered statistically significant.

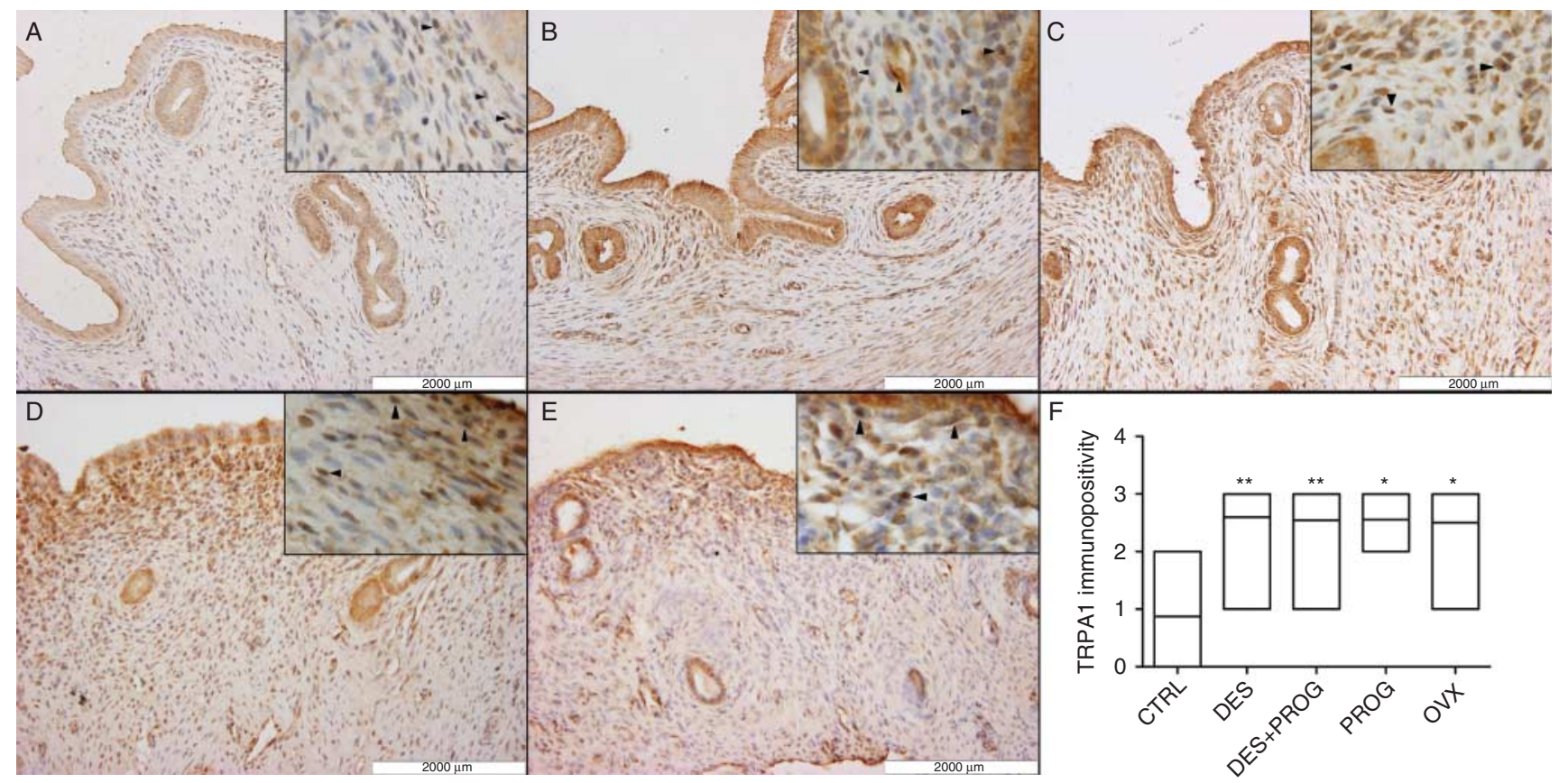

\section{Figure 2}

Representative photographs of TRPA1 receptor-immunopositive areas in the rat endometrium. Immunostaining of $(A)$ the untreated group compared with (B) DES-implanted, (C) progesterone-treated, (D) DES- and progesterone-treated and (E) ovariectomized groups, and (F) semiquantitative scoring of TRPA1 immunopositivity in 4-month-old animals.
Box plots with the whiskers represent the medians $\pm 25-75$ percentiles of the score values (Kruskal-Wallis with Dunn's post-test: ${ }^{\star} P<0.05$,

$* * P<0.005)$. Magnification: $200 \times$. A full colour version of this figure is available at http://dx.doi.org/10.1530/JME-15-0184. http://jme.endocrinology-journals.org DOI: $10.1530 / J M E-15-0184$
(C) 2016 Society for Endocrinology Printed in Great Britain
Published by Bioscientifica Ltd 


\section{Results}

\section{Trpa1, Trpv1 and Mif mRNA are expressed in the rat endometrium and up-regulated following estrogen treatment}

To quantify the expression of TRPA, TRPV1 and MIF in the endometrium, we measured their relative mRNA levels by qPCR compared with the housekeeping gene Ppia showing the most stable expression in the uterus independently of age (Rajat et al. 2013; Supplementary Figure 1, see section on supplementary data given at the end of this article).

Relative Trpa1 mRNA expression was significantly higher by about 8 - and 2.5-fold in the endometrium of DES-treated rats compared with the untreated ones both in the sexually mature (4-month-old; Fig. 1A) and immature (4-week-old; Fig. 1D) groups. When progesterone was administered in combination with DES, this elevation was absent, and progesterone alone did not induce Trpa1 mRNA increase in either age group (Fig. 1A and D). Although there was an increasing tendency after ovariectomy in mature rats, Trpa1 mRNA levels did not significantly change compared with the intact controls (Fig. 1A) or sham-operated animals (fold change 1.21).

Similarly to Trpa1, the relative expression of $\operatorname{Tr} p v 1$ also showed eight- and fivefold increases in response to DES treatment in the sexually mature (Fig. 1B) and immature
(Fig. 1E) rats respectively. After combining DES with progesterone or administering progesterone by itself, no significant change was observed in Trpv1 expression in either the young or older rats, and ovariectomy in the mature group did not significantly alter the expression levels in comparison with the intact (Fig. 1B and E) or sham-operated group (fold change 1.09).

DES induced a small, but significant 1.5 - and 2.5-fold Mif up-regulation in the mature (Fig. 1C) and immature (Fig. 1F) rats respectively. This elevation was absent when progesterone was added to DES, and progesterone in either age group or ovariectomy in the sexually matured animals did not significantly change the expression of Mif mRNA (Fig. 1C and F; sham-operated 1.19-fold).

\section{TRPA1, TRPV1 and MIF proteins are localized in rat endometrial cells and up-regulated by hormones}

In the control endometrium of sexually mature rats, there is a weak to moderate TRPA1 staining of the surface epithelium and glands, with scattered, weak staining of stromal cells close to the surface (Fig. 2A). Similar pattern and staining intensity was observed in the immature endometrium (Fig. 3A). The mature endometrium displayed weak TRPV1 labelling restricted mostly to the epithelium (Fig. 4A). The immature endometrium showed

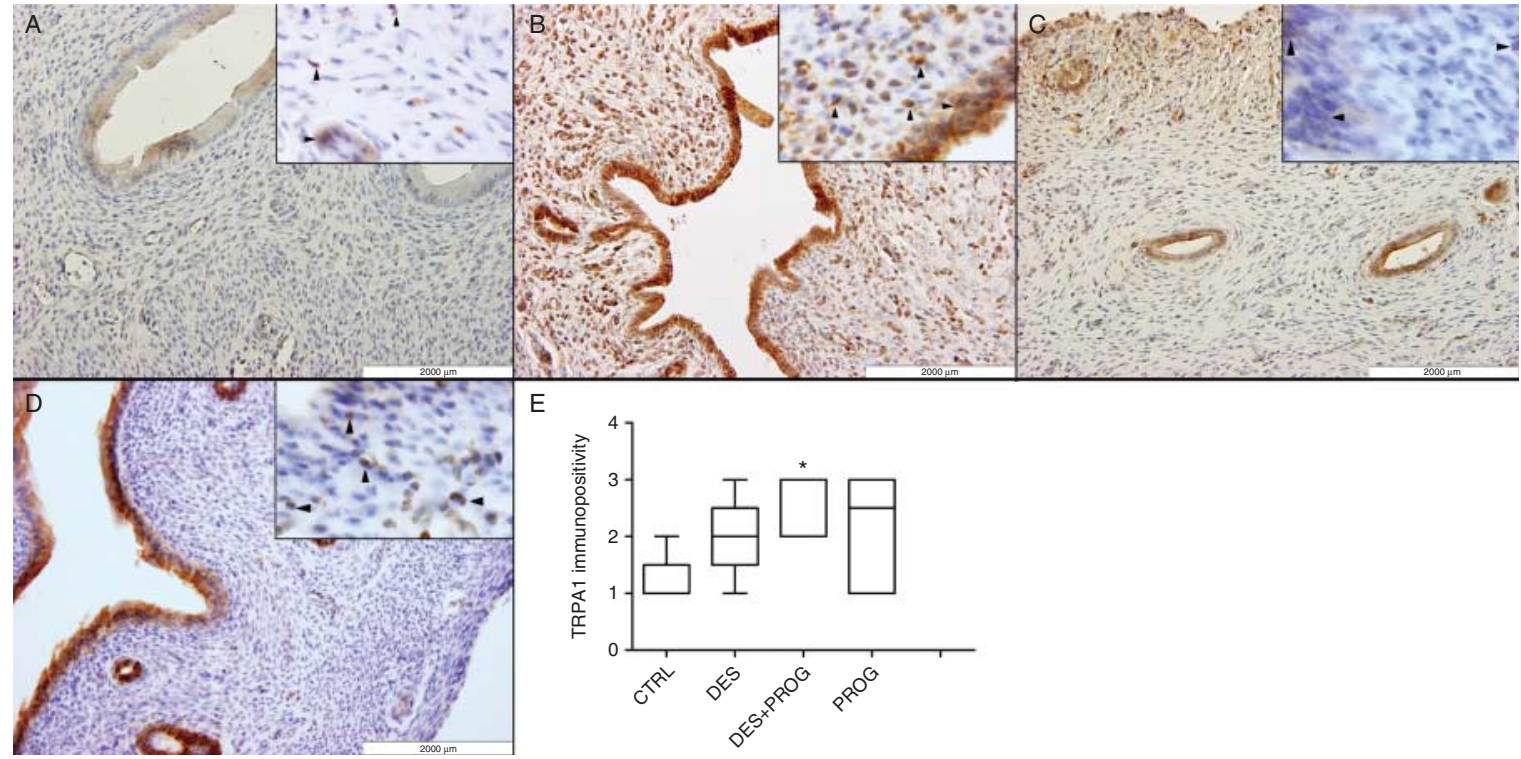

\section{Figure 3}

Representative photomicrographs of TRPA1-labelled (A) control, (B) DES-treated, (C) progesterone-implanted and (D) DES- and progesterone-treated groups, and $(\mathrm{E})$ semi-quantitative scoring of the sections in sexually immature 4-week-old rats. Box plots with the
(C) 2016 Society for Endocrinology Printed in Great Britain whiskers represent the medians $\pm 25-75$ percentiles of the score values (Kruskal-Wallis with Dunn's post-test: ${ }^{*} P<0.05$ ). Magnification: $200 \times$. A full colour version of this figure is available at http://dx.doi.org/10.1530/ JME-15-0184.

Published by Bioscientifica Ltd. 


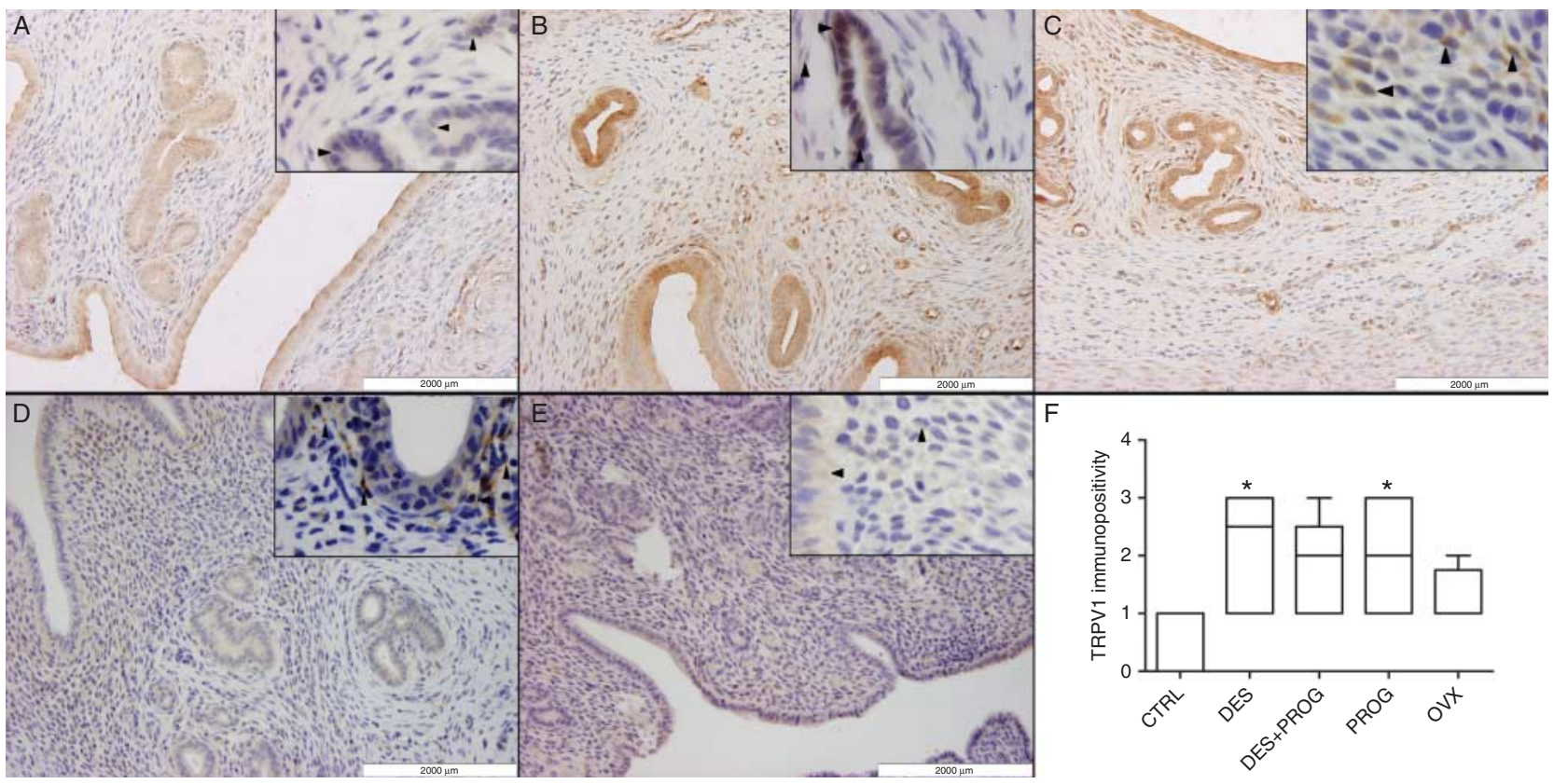

\section{Figure 4}

Representative photographs of TRPV1-labelled (A) control, (B) DES-treated, (C) progesterone-implanted, (D) DES- and progesterone-treated and (E) ovariectomized groups, and (F) semi-quantitative scoring of the sections in sexually mature 4-month-old rats. Box plots with the whiskers represent

no or minimal staining in the epithelial structures and no staining in the endometrial stroma (Fig. 5A). MIF showed moderate to strong staining in the endometrial glands and surface epithelium, while mild positivity was detectable in the stromal cells of both age groups (Figs 6A and 7A).

In sexually mature rats, all hormone treatments and ovariectomy equally elicited significantly increased intensity of TRPA1 immunopositivity in the epithelial layer and the glands (Fig. 2). In immature animals, DES treatment induced a considerable immunopositivity increase in the epithelium, while progesterone by itself and in combination with DES resulted in elevated positivity in the stroma near the epithelial layer when compared with the control group. However, only the combination treatment resulted in a statistically significant immunostaining intensity increase (Fig. 3).

In adult rats, TRPV1 immunopositivity was observed in the stroma and the glands with weak expression in the epithelium. DES and progesterone treatment caused significantly elevated immunopositivity in all areas; the combination resulted in a similar tendency, but ovariectomy did not alter the staining intensity (Fig. 4). In young animals, TRPV1 positivity significantly increased after DES and progesterone treatment in the stroma and the glands, while the epithelium showed weak expression (Fig. 5). the medians $\pm 25-75$ percentiles of the score values (Kruskal-Wallis with Dunn's post-test: $* P<0.05)$. Magnification: $200 \times$. A full colour version of this figure is available at http://dx.doi.org/10.1530/JME-15-0184.

Weak MIF expression detected in the epithelial layer and the stroma in control adult rats was more intensive after all the treatments, but only progesterone administration resulted in a significant increase focally in the epithelium (Fig. 6). In immature animals, the weak MIF immunopositivity detected in the epithelium and the surrounding stroma increased in all cases, but reached the level of statistical significance after progesterone and combination treatments (Fig. 7). The endometrial thickness was measured in all the experimental groups in five different sections of each animal and then averaged. There were no significant differences in any treatment groups, although the variations of the results were greater in sexually premature animals (Supplementary Figure 2, see section on supplementary data given at the end of this article). Negative control slides where the primary antibodies were not applied showed lack of immunostaining (Supplementary Figure 3).

\section{Functional TRPA1 and TRPV1 receptors are expressed on cultured primary rat endometrial cells}

Both the TRPA1 agonist formalin $(3.3 \mathrm{mM})$ and the TRPV1 activator capsaicin $(330 \mathrm{nM})$ evoked a rapid $\mathrm{Ca}^{2+}$ influx into the endometrial cells, providing functional

Published by Bioscientifica Ltd 


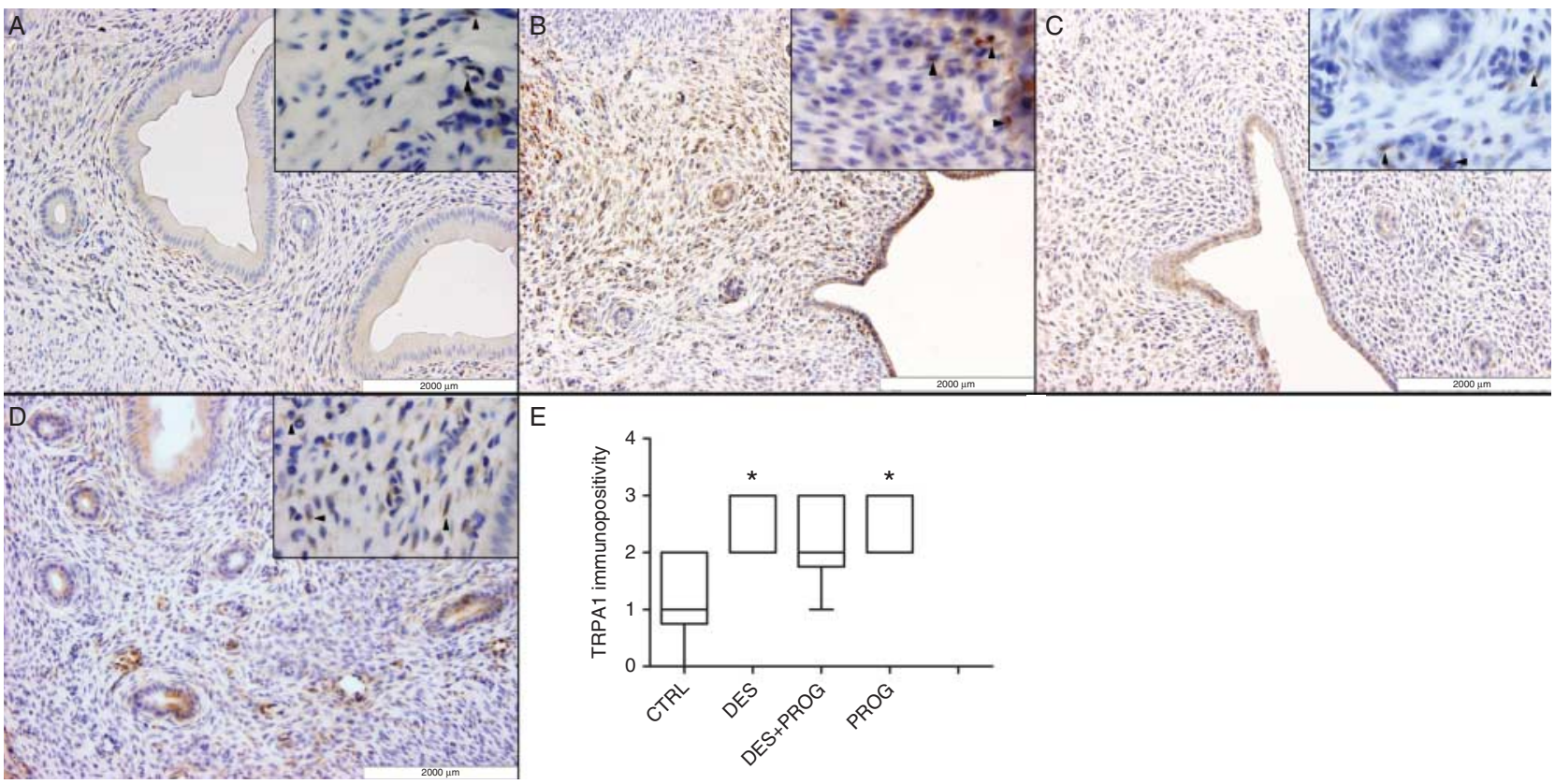

\section{Figure 5}

Representative immunohistochemical images of TRPV1-labelled (A) control, (B) DES-treated, (C) progesterone-implanted and (D) DES- and progesterone-treated groups, and (E) semi-quantitative scoring of the sections in sexually immature 4-week-old rats. Box plots with the whiskers

evidence for the presence of functional receptor proteins. Capsaicin caused a rapid, transient $\mathrm{Ca}^{2+}$ influx in the cytosol of epithelial cells as detected by the magnitude of the fluorescence response. The percentage of capsaicin-responsive cells was $10.84 \%$ ( 4 out of 37 ), and then after a 2 min wash period, the responses were reproducible. Formalin administration caused $\mathrm{Ca}^{2+}$ influx, which developed after 30-60 s latency. The percentage of cells responding to formaldehyde was $13.5 \%$ (5 out of 37) (Fig. 8A and B). Original responses to the repetitive stimuli by capsaicin and formaldehyde are shown in Fig. 8C and D.

\section{DES up-regulates Trpa1, Trpv1 and Mif mRNA in the primary cultures of rat endometrial cells}

Pre-incubation of the primary rat endometrial cell cultures for $18 \mathrm{~h}$ with $200 \mathrm{pM}$ of the non-selective $\mathrm{ER} \alpha / \mathrm{ER} \beta$ agonist synthetic compound DES used in our in vivo experiments induced 10-, 17- and 5-fold up-regulation of Trpa1, Trpv1 and Mif mRNA respectively. Meanwhile, 17ß-oestradiol having ER $\alpha$-selective agonist potency evoked a remarkable increase (about fivefold) only in the expression of Trpv1 (Fig. 8E, F and G). represent the medians $\pm 25-75$ percentiles of the score values (KruskalWallis with Dunn's post-test: $* P<0.05)$. Magnification: $200 \times$. A full colour version of this figure is available at http://dx.doi.org/10.1530/JME-15-0184.

However, the intensity of the fluorescent calcium signals in the endometrial cells and the number of responsive cells to the TRPV1 agonist capsaicin or the TRPA1 agonist formalin was not altered after the pre-incubation with either DES or $17 \beta$-oestradiol (data not shown).

\section{Chronic in vivo DES pre-treatment modulates MIF-induced Trpa1 and Trpv1 expression, as well as their activation-evoked iNOS and $/ / 1 b$ gene expression in endometrial cells}

In the primary cultures of rat endometrial cells, a 24-h incubation with $1 \mu \mathrm{g} \mathrm{MIF} / \mu \mathrm{l}$ induced an approximately threefold up-regulation of Trpa1 mRNA, but chronic (10-day-long) in vivo DES pretreatment caused a significantly greater increase (tenfold). MIF alone did not alter the expression of Trpv1 mRNA levels, but after chronic DES pretreatment, it caused a significant 2.5 -fold elevation in comparison with the placebo-treated animals. TRPA1 stimulation with $3.3 \mathrm{mM}$ formalin did not influence its own expression in the cells derived from the placebo-pretreated rats, but induced a significant 2.5 -fold up-regulation after chronic in vivo DES pretreatment.

Published by Bioscientifica Ltd 


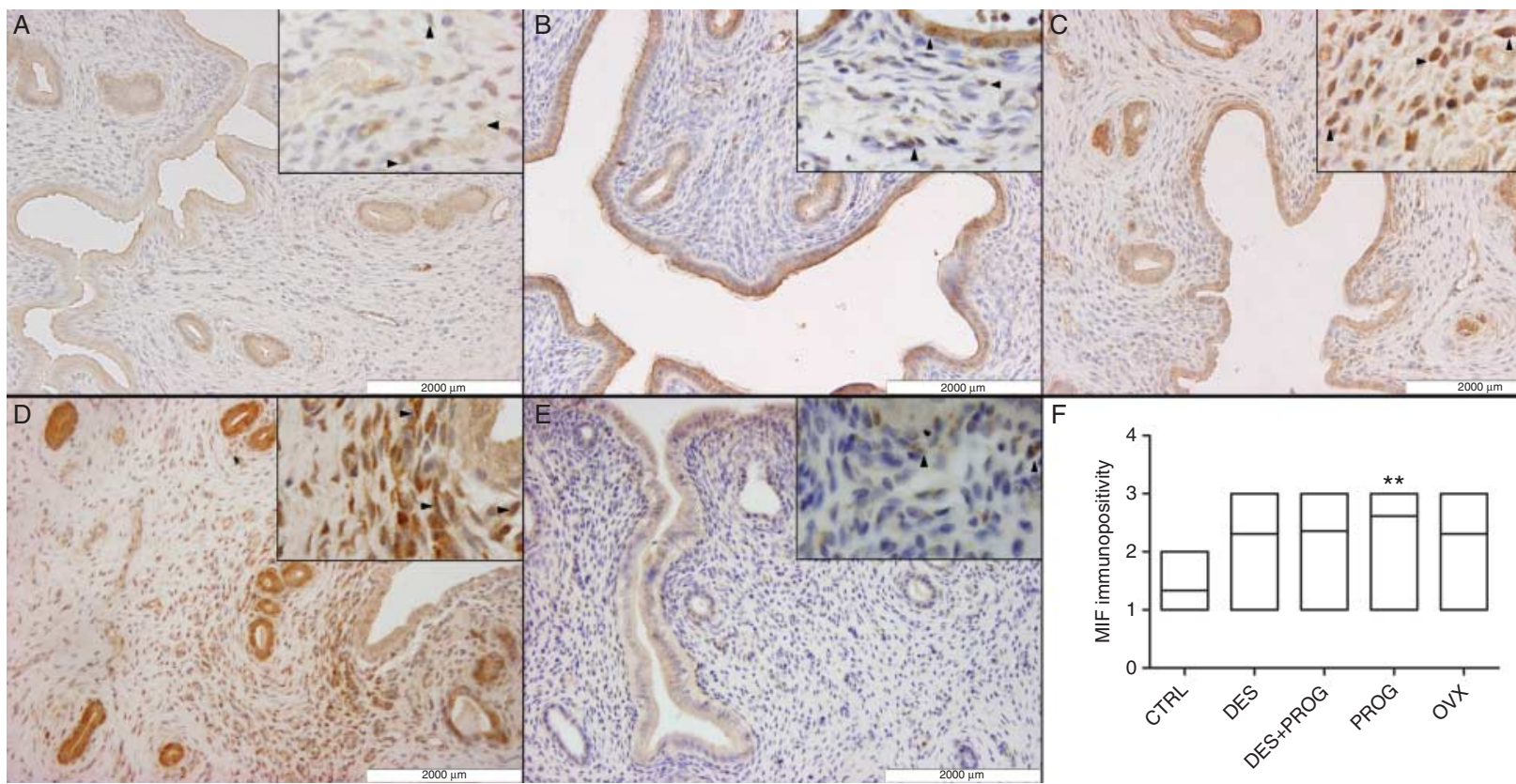

\section{Figure 6}

Immunohistochemical analysis of MIF in the rat uterus of (A) control, (B) DES-treated, (C) progesterone-implanted, (D) DES- and progesteronetreated, (E) ovariectomized groups, and (F) semi-quantitative scoring of the sections in sexually immature 4-month-old rats. Box plots with the whiskers

TRPV1 activation with $330 \mathrm{nM}$ capsaicin resulted in a 30-fold increase of Trpv1 mRNA in the cells obtained from the placebo-pretreated animals, but a significantly greater increase (40-fold) in the endometrial cell cultures of the DES pretreated ones (Fig. 9A).

In endometrial cells obtained from the chronically DES-pretreated rats, TRPA1 (but not TRPV1) activationinduced iNOS mRNA up-regulation was significantly decreased, but both TRPV1 and TRPA1 stimulation-evoked Il1 $b$ mRNA increases were significantly reduced when compared with placebo pretreatment (Fig. 9B).

\section{Discussion}

The endometrium undergoes continuous dynamic changes, such as proliferation, differentiation, regeneration and disintegration, in response to fluctuating estrogen and progesterone levels modulated by peptide hormones, growth factors and cytokines produced locally by various cell types (von Wolff et al. 2000, Srisuparp et al. 2001). The well-established morphological and functional changes during the different phases of the hormonal cycle result from complex gene transcription alterations responsible for divergent molecular pathways, which are not yet fully understood. represent the medians $\pm 25-75$ percentiles of the score values (Kruskal-Wallis with Dunn's post-test: $* * P<0.005)$. Magnification: $200 \times$. A full colour version of this figure is available at http://dx.doi.org/10.1530/ JME-15-0184.

The present study reports Trpa1 mRNA expression in the rat endometrium, and hormone-dependent up-regulation of TRPA1 and TRPV1 in correlation with the inflammatory cytokine MIF in both sexually immature and mature animals. The estrogen-induced TRPA1, TRPV1 and MIF increase suggests their potential roles in normal endometrial functions during the reproductive cycle, which might also be extrapolated to pathological conditions with pain and inflammation (Suzuki et al. 1996, Akoum et al. 2006, Liu et al. 2012).

We describe an estrogen-specific up-regulation of Trpa1/Trpv1 mRNA in the endometrium and also provide evidence for the functionality of these receptor proteins in cultured primary endometrial cells. Specific TRPA1/TRPV1 activation provoked an up-regulation of respective receptor mRNA in endometrial cell cultures. This can be a further evidence for receptor functionality, but a compensatory reaction to receptor desensitization cannot be excluded (Biro et al. 1998, Czikora et al. 2013). MIF administration also increased Trpa1/Trpv1 mRNA levels. Specific up-regulation of Trpv1 transcripts in isolated human leukocytes has been described in response to elevated serum MIF levels in a case study (Bachiocco et al. 2011), but we demonstrate the first functional evidence of MIF-TRP signalling augmented by the chronic estrogen

Published by Bioscientifica Ltd. 


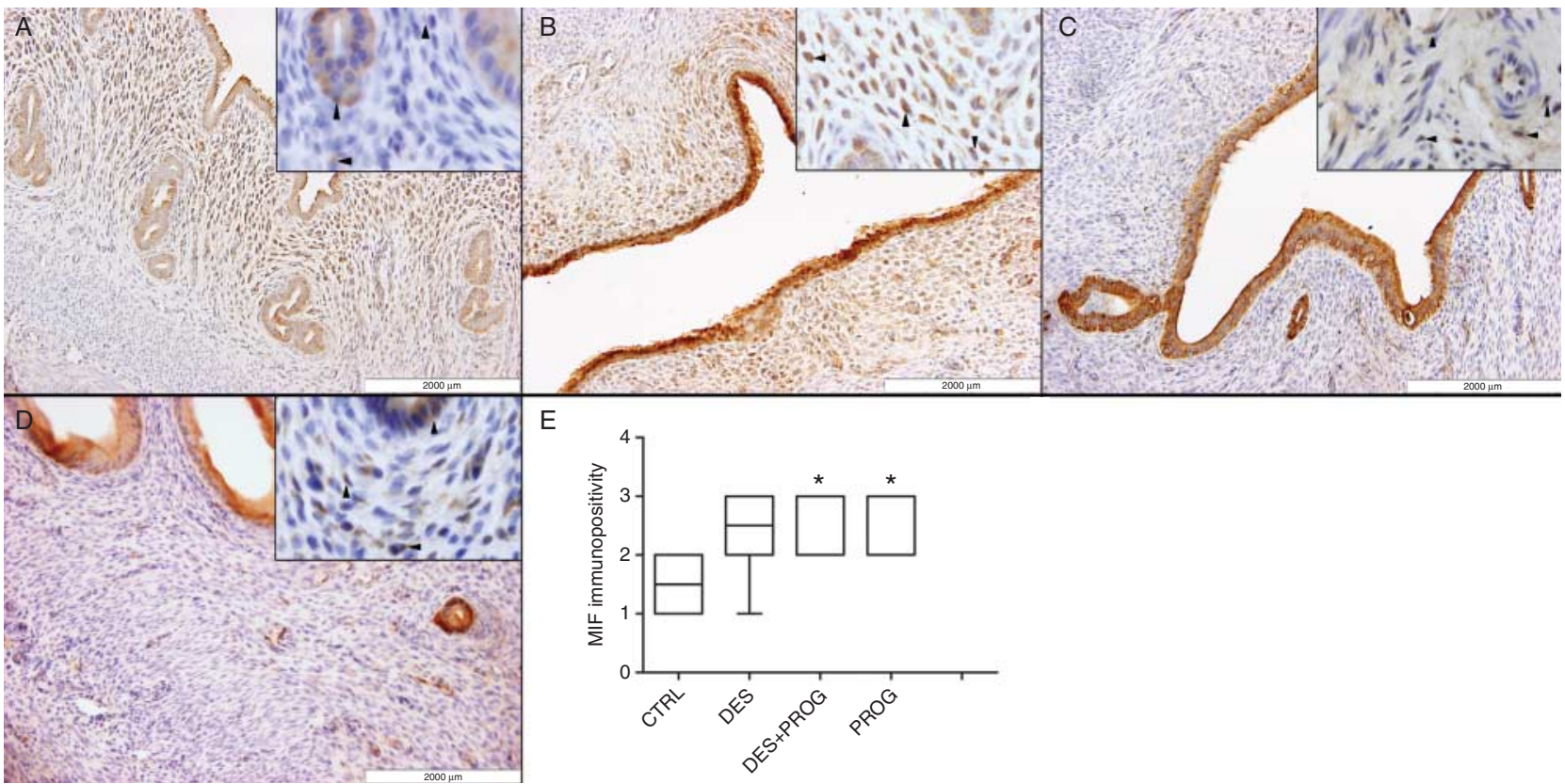

Figure 7

Immunohistochemical analysis of MIF in the rat uterus of (A) control, (B) DES-treated, (C) progesterone-implanted and (D) DES- and progesterone-treated groups, and (E) semi-quantitative scoring of the sections in sexually immature 4-week-old rats. Box plots with the whiskers

effect. Specific TRPA1/TRPV1 stimulation resulted in the elevated levels of $i N O S$ and $I l 1 b$ mRNA, pointing to functional relevance of endometrial TRP channels. These mediators play roles in the local control of the endometrium during the normal hormonal cycle, e.g. vasodilation $(\mathrm{NO})$ and pro-inflammatory responses during ovulation, pregnancy or inhibition of decidualization (IL1B) (Telfer et al. 1997, Mizuno et al. 1999, Wira et al. 2010). Moreover, both are released from ectopic endometrial cells upon TRPA1/TRPV1 activation (Greaves et al. 2014). Il1b and iNOS transcripts were down-regulated after TRPA1/TRPV1 activation in the cells obtained form the DES-pretreated animals. Transcriptional responses after prolonged effects of DES can reflect an estrogen-driven signalling and underlying gene expression patterns: MIF levels are cycle-dependent in the human endometrium (Kats et al. 2005), Il1b is down-regulated (Wira et al. 2010), while $i N O S$ is regulated by estrogen action in a complex manner (Han et al. 2005).

TRPV1 mediates NO and IL1B release in human endometriosis (Hucho \& Levine 2007, Liu et al. 2012). Stimulation of TRPV1 in rat C fibres is dependent on the oestrous cycle favouring oestradiol (Peng et al. 2008), and oestradiol may contribute to pain through TRPV1 represent the medians $\pm 25-75$ percentiles of the score values (Kruskal-Wallis with Dunn's post-test: ${ }^{*} P<0.05$ ). Magnification: $200 \times$ A full colour version of this figure is available at http://dx.doi.org/10.1530/ JME-15-0184.

regulation in the hippocampus (Wu et al. 2010). It exerts classical (slow, genomic) effects on Trpv transcription (Hoenderop et al. 2005) and can also directly or indirectly stimulate the TRPV1 receptor (Kumar et al. 2014). In contrast to mRNA, progesterone also increased TRPA1 and TRPV1 protein expression levels in the endometrium, possibly due to sensory neural expression, local translational/protein degradation differences or mRNA contribution of different cell types. Progesterone is also well known to mediate $\beta_{2}$-adrenergic receptor transcription (Vivat et al. 1992) and eventually might have an indirect effect on TRPV1 signalling, but no direct modulation has been described so far (Kumar et al. 2014).

Ovariectomy resulted in increasing Trpa1/Trpv1 and Mif mRNA expression tendencies, and significant TRPA1 protein up-regulation in the endometrium. Reduced estrogen effects (e.g. after ovariectomy) up-regulate or stimulate TRPV1 and increase pain/hyperalgesia (Idris et al. 2010, Wu et al. 2010, Rossi et al. 2014). According to a well-proven explanation, high estrogen levels determine a female phenotype of signalling pathways downstream of the $\beta_{2}$ adrenergic receptor, such as attenuated protein kinase $\mathrm{A}$ and $\mathrm{C} \varepsilon$ activities (Hucho \& Levine 2007). Ovariectomy alleviates suppression of these

Published by Bioscientifica Ltd 

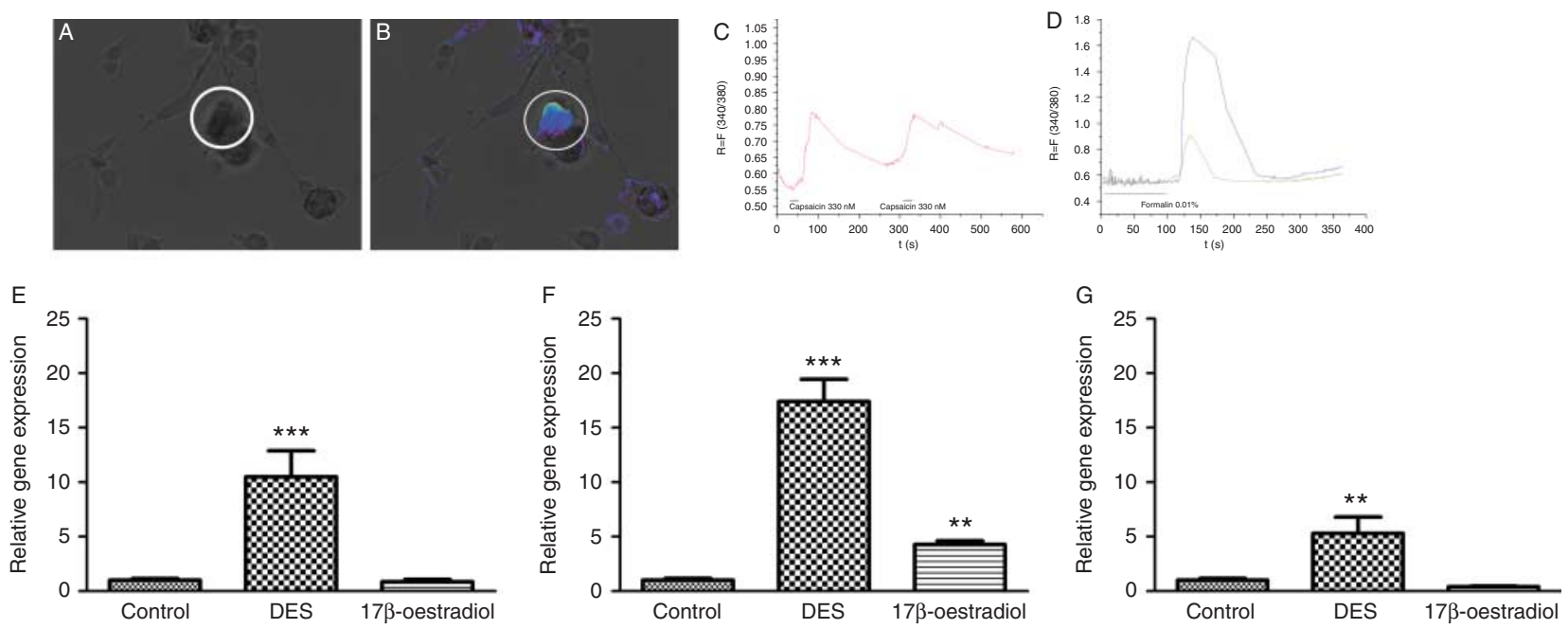

\section{Figure 8}

(A and B) Representative transmitted light pseudocolour images of a rat endometrial cell before and after the application of the TRPV1 agonist capsaicin $(330 \mathrm{nM})$. Original recordings showing the responses induced by (C) repetitive capsaicin and (D) the TRPA1 agonist formalin (3.3 mM) stimuli. Relative gene expression of (E) Trpa1, (F) Trpv1 and (G) Mif mRNA after an 18-h administration of DES and 17 $\beta$-oestradiol ( $n=4 /$ group).

protein kinases that are known to activate or sensitize TRPV1 (Goswami et al. 2011). This was described in neurons where reduced estrogen levels provoke pain/ hyperalgesia (Idris et al. 2010, Wu et al. 2010, Rossi et al. 2014). Ovariectomy also increases non-neuronal TRPV1 and MIF expression (Kastin et al. 1992, Oshima et al. 2006, Emmerson et al. 2009, Idris et al. 2010, Wu et al. 2010, Kahnamoei 2012, Rossi et al. 2014). Endometrial cells express the $\beta_{2}$ adrenergic receptor (Ontsouka et al. 2004, Bruzzone et al. 2005); therefore, it is reasonable to explain our ovariectomy-evoked results by this noradrenaline-dependent system.
Fold changes represent respective mRNA levels normalized to the Ppia as a housekeeping gene following the $\Delta \Delta C T$ method. Each column shows the ratio of relative gene expression (mean \pm s.E.M.; one-way ANOVA with Dunnett's multiple comparison test: $* * P<0.005, * * * P<0.0001)$. A full colour version of this figure is available at http://dx.doi.org/10.1530/ JME-15-0184.

We demonstrated that Mif transcription is regulated by DES in the rat endometrium in parallel with Trpa1/Trpv1 mRNA levels. Its expression is mediated by estrogen levels, while ovariectomy also increases MIF expression. Beside its functions in innate immunity, MIF is a potent angiogenic, anti-apoptotic, proliferative and tissue remodelling factor (Calandra \& Roger 2003) partly by acting on the CD74 receptor (Leng et al. 2003). It is expressed cycle-dependently in human endometrial epithelial and stromal compartments (Kats et al. 2005).

In order to assess the involvement of $\operatorname{ER} \alpha$ and $\operatorname{ER} \beta$ in the estrogen-driven up-regulation of these molecules, the
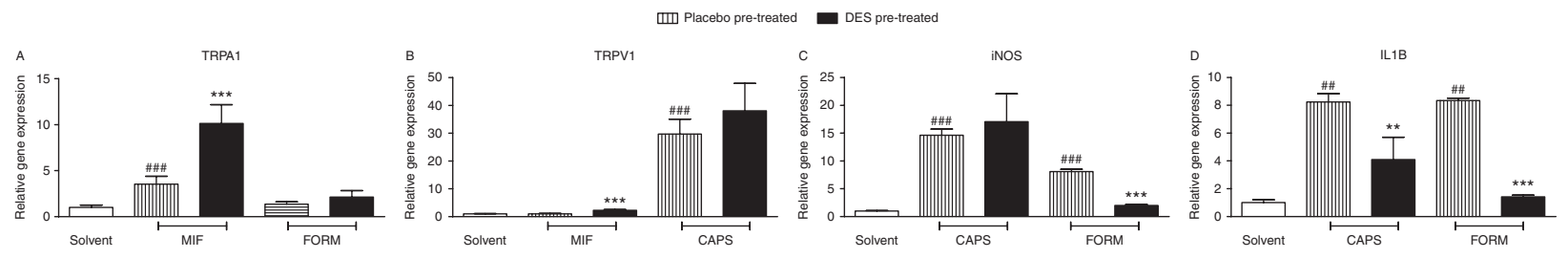

Figure 9

Relative mRNA expression of (A) Trpa1 and (B) Trpv1 receptors, as well as (C) iNOS and (D) $/ 11 b$ in the primary endometrial cell cultures derived from chronically DES-pretreated or placebo-pretreated rats in response to

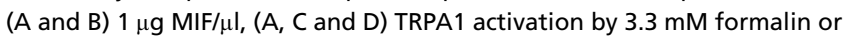
(B, C and D) TRPV1 stimulation by $330 \mathrm{nM}$ capsaicin ( $n=4 /$ group).
Fold change represents respective mRNA levels normalized to Ppia as a housekeeping gene following the $\Delta \Delta C T$ method. Each column shows the ratio of relative gene expression (mean \pm s.E.M.; one-way ANOVA with Dunnett's multiple comparison test: ${ }^{\# \#} P<0.005$, ${ }^{\# \#} P<0.0001$ vs solventtreated cells and $* * P<0.005, * * * P<0.0001$ vs placebo-treated group).

Published by Bioscientifica Ltd. 
primary rat endometrial cell cultures were pre-incubated with the non-selective ER $\alpha / \operatorname{ER} \beta$ agonist synthetic compound DES in comparison with $17 \beta$-oestradiol having ER $\alpha$-selective agonist potency. DES up-regulated Trpa1, Trpv1 and Mif mRNA in this in vitro system, similarly to our whole tissue results following the in vivo treatment. Meanwhile, only Trpv1 transcription increased in response to $17 \beta$-oestradiol, suggesting that ER $\beta$ might also play a role in the regulation of TRPA1, TRPV1 and MIF. Despite the marked up-regulation of these molecules, fluorescent calcium signal intensity and number of endometrial cells responsive to TRPV1/TRPA1 activation were not altered after pre-incubation with either DES or $17 \beta$-oestradiol. This might be due to intracellular calcium signals being regulated by several different mechanisms including the contribution of intracellular stores; therefore, this technique is less suited for quantitative analysis. Moreover, another possible explanation is that TRP receptors in the endometrium may play a role in signal transduction pathways similarly to $\mathrm{Na}^{+} / \mathrm{K}^{+}$-ATPase that is involved in the assembly of multiple protein complexes transmitting signals to different intracellular compartments (Xie \& Cai 2003). Further studies are needed to determine this issue and draw a conclusion on the mechanism.

Based on literature data obtained in keratinocytes, synoviocytes, endometriosis cells and placenta (Cella et al. 2008, Fernandes et al. 2012, Liu et al. 2012, Nilius \& Szallasi 2014, Wu et al. 2015), IL1A and IL1B, NO, prostaglandin $\mathrm{E}_{2}$, substance $\mathrm{P}, \mathrm{IL} 8$ and matrix metalloproteinase-1 release can be proposed from endometrial cells upon TRPA1/TRPV1 activation/sensitization by estrogen. Beside their involvement in pain/inflammation, these mediators play physiological roles in reproductive, reparative and inflammatory-like processes of the normal endometrium (Curry \& Osteen 2003, Goff 2004, Thippeswamy 2006, Wira et al. 2010).

Endometrial TRPA1 and TRPV1 receptors have an estrogen-regulated expression pattern similar to dorsal root ganglion primary sensory neurons innervating the area and also other cell types (Hoenderop et al. 2005, Greaves et al. 2014). This indicates that they might play a role in estrogen-evoked signal generation and transmission in conditions with altered sex hormone levels. Similarly to other TRP or cation channels of the endometrium (Ruan et al. 2014, Singh et al. 2015), TRPA1/TRPV1 may mediate homeostatic and barrier functions, $\mathrm{Ca}^{2+}$ signalling, cell proliferation/differentiation, endometrial receptivity, embryo implantation and sensory-immune interactions (Fernandes et al. 2012). Non-neuronal TRPV1 can also be activated by the endocannabinoid anandamide in the rat reproductive system (Cella et al. 2008, Scotchie et al. 2014).

These results are consistent with increased TRPA 1 and TRPV1 expression in rat and human endometriosis demonstrated by our laboratory (unpublished results) and literature data (Hucho \& Levine 2007, Ilie \& Ilie 2013, Graham et al. 2015). Increased estrogen synthesis in endometriosis lesions makes those results comparable to these data. Furthermore, the TRP agonist endocannabinoids regulate the migration of endometrial stromal cells (Gentilini et al. 2010). TRPA1/TRPV1 in non-neural cells (stromal, glandular and epithelial cells) might have estrogen-mediated normal sensory, secretory and consequent inflammation-generating and pain-transmitting roles under pathological conditions. Although not investigated by the present study, non-neural TRP channels may amplify pain/inflammatory signals under pathological conditions as described in keratinocytes (Pang et al. 2015) and synoviocytes (Wu et al. 2015).

The present results provide the first evidence that i) functional non-neuronal TRPA1 and TRPV1 receptor proteins are expressed in the rat endometrium, ii) their expressions are regulated by estrogen and positively correlate with the oestrus cycle-dependent regulatory factor MIF, iii) MIF significantly increases TRPA1 and TRPV1 expression and iv) chronic estrogen action increases TRPA1/TRPV1 activation-induced iNOS and Il1b mRNA up-regulation being involved in endometrial homeostasis.

Supplementary data

This is linked to the online version of the paper at http://dx.doi.org/10.1530/ JME-15-0184

Declaration of interest

The authors declare that there is no conflict of interest that could be perceived as prejudicing the impartiality of the research reported.

\section{Funding}

This research was supported by the Hungarian grant KTIA_NAP_13-20140022 (MTA-PTE NAP B Pain Research Group, identification number: 888819). J K was supported by a scholarship from the European Union and the State of Hungary, co-financed by the European Social Fund in the framework of TÁMOP-4.2.4.A/2-11/1-2012-0001 'National Excellence Program'.

\section{Author contribution statement}

$K P, J K, B S, J G, L C$ and $Z s ~ H$ conceived and designed the experiments. $K P$, J K, B S, E S Z, E S, M P and A P performed the experiments. K P, A G, B K and $K K$ analysed the data. J L K contributed reagents, materials and analysis tools. K P, J K, B S, J L K, J G and Zs H wrote the paper.

Published by Bioscientifica Ltd. 


\section{References}

Akoum A, Metz CN, Al-Akoum M \& Kats R 2006 Macrophage migration inhibitory factor expression in the intrauterine endometrium of women with endometriosis varies with disease stage, infertility status, and pelvic pain. Fertility and Sterility 85 1379-1385. (doi:10.1016/ j.fertnstert.2005.10.073)

Assas BM, Miyan JA \& Pennock JL 2014 Cross-talk between neural and immune receptors provides a potential mechanism of homeostatic regulation in the gut mucosa. Mucosal Immunology 7 1283-1289. (doi:10.1038/mi.2014.80)

Bacher M, Meinhardt A, Lan HY, Dhabhar FS, Mu W, Metz CN, Chesney JA, Gemsa D, Donnelly T, Atkins RC et al. 1998 MIF expression in the rat brain: implications for neuronal function. Molecular Medicine 4 217-230.

Bachiocco V, Bergamaschi R, Spinsanti G, Lima M, Romagnoli R, Sorda G \& Aloisi AM 2011 Lymphocyte TRPV 1-4 gene expression and MIF blood levels in a young girl clinically diagnosed with HSAN IV. Clinical Journal of Pain 27 631-634. (doi:10.1097/AJP.0b013e3182119356)

Barkhem T, Carlsson B, Nilsson Y, Enmark E, Gustafsson J \& Nilsson S 1998 Differential response of estrogen receptor $\alpha$ and estrogen receptor $\beta$ to partial estrogen agonists/antagonists. Molecular Pharmacology $\mathbf{5 4}$ 105-112. (doi:10.1124/mol.54.1.105)

Biro T, Maurer M, Modarres S, Lewin NE, Brodie C, Acs G, Acs P, Paus R \& Blumberg PM 1998 Characterization of functional vanilloid receptors expressed by mast cells. Blood 91 1332-1340.

Bruzzone ME, Fabres C, Benitez DA, Castellon EA \& Zegers-Hochschild F 2005 Influence of embryonic conditioned media upon the endometrial $\beta$-adrenergic receptor. Reproductive Biomedicine Online 11 58-63. (doi:10.1016/S1472-6483(10)61299-0)

Calandra T \& Roger T 2003 Macrophage migration inhibitory factor: a regulator of innate immunity. Nature Reviews. Immunology 3 791-800. (doi:10.1038/nri1200)

Cella M, Leguizamón GF, Sordelli MS, Cervini M, Guadagnoli T, Ribeiro ML, Franchi AM \& Farina MG 2008 Dual effect of anandamide on rat placenta nitric oxide synthesis. Placenta 29 699-707. (doi:10.1016/ j.placenta.2008.05.003)

Curry TE Jr \& Osteen KG 2003 The matrix metalloproteinase system: changes, regulation, and impact throughout the ovarian and uterine reproductive cycle. Endocrine Reviews 24 428-465. (doi:10.1210/er. 2002-0005)

Czikora A, Rutkai I, Pasztor TE, Szalai A, Porszasz R, Boczan J, Edes I, Papp Z \& Toth A 2013 Different desensitization patterns for sensory and vascular TRPV1 populations in the rat: expression, localization and functional consequences. PLOS ONE 8 e78184. (doi:10.1371/journal. pone.0078184)

David JR 1966 Delayed hypersensitivity in vitro: its mediation by cell free substances forms by lymphoid cell-antigen interaction. PNAS $\mathbf{5 6}$ 72-77. (doi:10.1073/pnas.56.1.72)

Denda S, Denda M, Inoue K \& Hibino T 2010 Glycolic acid induces keratinocytes proliferation in a skin equivalent model via TRPV1 activation. Journal of Dermatological Science 57 108-113. (doi:10.1016/ j.jdermsci.2009.11.007)

Emmerson E, Campbell L, Ashcroft GS \& Hardman MJ 2009 Unique and synergistic roles for $17 \beta$-estradiol and macrophage migration inhibitory factor during cutaneous wound closure are cell type specific. Endocrinology 150 2749-2757. (doi:10.1210/en.2008-1569)

Fernandes ES, Fernandes MA \& Keeble JE 2012 The functions of TRPA1 and TRPV1: moving away from sensory nerves. British Journal of Pharmacology 166 510-521. (doi:10.1111/j.1476-5381.2012.01851.x)

Garai J \& Clark JH 1992 Tyrosine-like activity and oestradiol binding in rat uterine nuclear extracts. Steroids 57 248-256. (doi:10.1016/0039128X(92)90110-U)

Gentilini D, Besana A, Vigano P, Dalino P, Vignali M, Melandri M, Busacca M \& Di Blasio AM 2010 Endocannabinoid system regulates migration of endometrial stromal cells via cannabinoid receptor 1 through the activation of PI3K and ERK1/2 pathways. Fertility and Sterility 93 2588-2593. (doi:10.1016/j.fertnstert.2010.02.006)

Goff AK 2004 Steroid hormone modulation of prostaglandin secretion in the ruminant endometrium during the estrous cycle. Biology of Reproduction 71 11-16. (doi:10.1095/biolreprod.103.025890)

Goswami C, Kuhn J, Dina OA, Fernández-Ballester G, Levine JD, FerrerMontiel A \& Hucho T 2011 Oestrogen destabilizes microtubules through an ion-conductivity-independent TRPV1 pathway. Journal of Neurochemistry 117 995-1008. (doi:10.1111/j.1471-4159. 2011.07270.x)

Graham A, Falcone T \& Nothnick WB 2015 The expression of microRNA-451 in human endometriotic lesions is inversely related to that of macrophage migration inhibitory factor (MIF) and regulates MIF expression and modulation of epithelial cell survival. Human Reproduction 30 642-652. (doi:10.1093/humrep/dev005)

Greaves E, Kelsey G, Andrew WH \& Saunders PT 2014 Elevated peritoneal expression and oestrogen regulation of nociceptive ion channels in endometriosis. Journal of Clinical Endocrinology and Metabolism 99 1738-1743. (doi:10.1210/jc.2014-2282)

Han G, Magee T \& Khorram O 2005 Regulation of nitric oxide synthase isoforms by estrogen in the human endometrium. Fertility and Sterility 84 1220-1227. (doi:10.1016/j.fertnstert.2005.06.016)

Herbison AE 2009 Rapid actions of oestrogen on gonadotropin-releasing hormone neurons; from fantasy to physiology? Journal of Physiology $\mathbf{1}$ 5025-5030. (doi:10.1113/jphysiol.2009.179838)

Hoenderop JG, Nilius B \& Bindels RJ 2005 Calcium absorption across epithelia. Physiological Reviews 85 373-422. (doi:10.1152/physrev. 00003.2004)

Hucho T \& Levine JD 2007 Signaling pathways in sensitization: toward nociceptor cell biology. Neuron 55 365-376. (doi:10.1016/j.neuron. 2007.07.008)

Idris AI, Landao-Bassonga E \& Ralston SH 2010 The TRPV1 ion channel antagonist capsazepine inhibits osteoclast and osteoblast differentiation in vitro and ovariectomy induced bone loss in vivo. Bone $\mathbf{4 6}$ 1089-1099. (doi:10.1016/j.bone.2010.01.368)

Ilie I \& Ilie R 2013 Cytokines and endometriosis—-the role of immunological alterations. Biotechnology, Molecular Biology and Nanomedicine 1 8-19.

Kahnamoei MJ 2012 Influence of ovariectomy on the MIF levels of spinal cord injury induced central pain syndrome in female rats. Research in Pharmaceutical Sciences 7 S60.

Kastin AJ, Fabre L, Brown MM \& Olson RD 1992 Age-and sex-related changes in Tyr-MIF-1-like immunoreactivity in rat plasma. Neuroendocrinology 56 902-906. (doi:10.1159/000126322)

Kats R, Al-Akoum M, Guay S, Metz C \& Akoum A 2005 Cycle-dependent expression of macrophage migration inhibitory factor in the human endometrium. Human Reproduction 20 3518-3525. (doi:10.1093/ humrep/dei234)

Kornyei JL, Oszter A, Kovacs KA, Vertes Zs, Komlosi KM, Gocze PM \& Vertes M 2001 Anti-mitogenic action of opioid peptides on epidermal growth factor-stimulated uterine cells. European Journal of Pharmacology 414 155-163. (doi:10.1016/S0014-2999(01)00790-7)

Kumar A, Kumari S, Majhi RK, Swain N, Yadav M \& Goswami C 2014 Regulation of TRP channels by steroids: implications in physiology and diseases. General and Comparative Endocrinology 220 23-32. (doi:10.1016/j.ygcen.2014.10.004)

Kun J, Helyes Zs, Perkecz A, Ban A, Polgar B, Szolcsanyi J \& Pinter E 2012 Effect of surgical and chemical sensory denervation on non-neural expression of the Transient Receptor Potential Vanilloid 1 (TRPV1) receptors in rat. Journal of Molecular Neuroscience $\mathbf{4 8}$ 795-803. (doi:10.1007/s12031-012-9766-9)

Leng L, Metz CN, Fang Y, Xu J, Donnelly S, Baugh J, Delohery T, Chen Y, Mitchell RA \& Bucala R 2003 MIF signal transduction initiated by binding to CD74. Journal of Experimental Medicine 197 1467-1476. (doi:10.1084/jem.20030286) 
Lin S, Yu X, Chen Y, Huang XR, Metz C, Bucala R, Lau C \& Lan H 2000 De novo expression of macrophage migration inhibitory factor in atherogenesis in rabbits. Circulation Research 87 1202-1208. (doi:10.1161/01.RES.87.12.1202)

Liu J, Liu X, Duan K, Zhang Y \& Guo SW 2012 The expression and functionality of transient receptor vanilloid 1 in ovarian endometriomas. Reproductive Sciences 19 1110-1124. (doi:10.1177/ 1933719112443876)

Mezey E, Toth ZE, Cortright DN, Arzubi MK, Krause JE, Elde R, Guo A, Blumberg PM \& Szallasi A 2000 Distribution of mRNA for vanilloid receptor subtype 1 (VR1) and VR1-like immunoreactivity, in the central nervous system of the rat and human. PNAS 97 3655-3660. (doi:10.1073/pnas.97.7.3655)

Mizuno K, Tanaka T, Umesaki N \& Ogita S 1999 Inhibition of cAMPmediated decidualization in human endometrial stromal cells by IL-1 $\beta$ and laminin. Hormone and Metabolic Research 31 307-310. (doi:10.1055/ s-2007-978742)

Nagata K 2007 TRP channels as target sites for insecticides: physiology, pharmacology and toxicology. Invertebrate Neuroscience 7 31-37. (doi:10.1007/s10158-007-0044-4)

Nilius B \& Szallasi A 2014 Transient receptor potential channels as drug targets: from the science of basic research to the art of medicine. Pharmacological Reviews 66 676-814. (doi:10.1124/pr.113.008268)

Nishihira J 2000 Macrophage migration inhibitory factor (MIF): its essential role in the immune system and cell growth. Journal of Interferon \& Cytokine Research 20 751-762. (doi:10.1089/ 10799900050151012)

Ontsouka EC, Reist M, Graber H, Blum JW, Steiner A \& Hirsbrunner G 2004 Expression of messenger RNA coding for 5-HT receptor, alpha and beta adrenoreceptor (subtypes) during oestrus and dioestrus in the bovine uterus. Journal of Veterinary Medicine Series A 51 (9-10) 385-393. (doi:10.1111/j.1439-0442.2004.00667.x)

Oshima S, Onodera S, Amizuka N, Li M, Irie K, Watanabe S, Koyama Y, Nishihara J, Yasuda K \& Minami A 2006 Macrophage migration inhibitory factor-deficient mice are resistant to ovariectomy-induced bone loss. FEBS Letters 580 1251-1256. (doi:10.1016/j.febslet.2006.01.038)

Pang Z, Sakamoto T, Tiwari V, Kim YS, Yang F, Dong X, Güler AD, Guan Y \& Caterina MJ 2015 Selective keratinocyte stimulation is sufficient to evoke nociception in mice. Pain 156 656-665. (doi:10.1097/ j.pain.0000000000000092)

Paterni I, Granchi C, Katzenellenbogen JA \& Minutolo F 2014 Estrogen receptors alpha $(E R \alpha)$ and beta (ER $\beta)$ : subtype-selective ligands and clinical potential. Steroids 90 13-29. (doi:10.1016/ j.steroids.2014.06.012)

Peng HY, Huang PC, Liao JM, Tung KC, Lee SD, Cheng CL, Shyu JC, Lai CY, Chen GD \& Lin TB 2008 Estrous cycle variation of TRPV1-mediated cross-organ sensitization between uterus and NMDA-dependent pelvic-urethra reflex activity. American Journal of Physiology. Endocrinology and Metabolism 295 559-568. (doi:10.1152/ajpendo. 90289.2008)

Pfaffl MW 2001 A new mathematical model for relative quantification in real-time RT-PCR. Nucleic Acids Research 29 45. (doi:10.1093/ nar/29.9.e45)

Potolicchio I, Santambrogio L \& Strominger JL 2003 Molecular interaction and enzymatic activity of macrophage migration inhibitory factor with immunorelevant peptides. Journal of Biological Chemistry 278 30889-30895. (doi:10.1074/jbc.M302854200)

Rajat KD, Sarmistha B \& Bernard HS 2013 Extensive sex- and/or hormonedependent expression of rat housekeeping genes. Endocrine Research 38 105-111. (doi:10.3109/07435800.2012.723294)

Rocha MG, Silva JC, Ribeiro da Silva A, Candido Dos Reis FJ, Nogueira AA \& Poli-Neto OB 2011 TRPV1 expression on peritoneal endometriosis foci is associated with chronic pelvic pain. Reproductive Sciences 18 511-515. (doi:10.1177/1933719110391279) Printed in Great Britain
Rossi F, Bellini G, Torella M, Tortora C, Manzo I, Giordano C, Guida F, Luongo L, Papale F, Rosso F et al. 2014 The genetic ablation or pharmacological inhibition of TRPV1 signalling is beneficial for the restoration of quiescent osteoclast activity in ovariectomized mice. British Journal of Pharmacology 171 2621-2630. (doi:10.1111/bph. 12542)

Ruan YC, Chen H \& Chan HC 2014 Ion channels in the endometrium: regulation of endometrial receptivity and embryo implantation. Human Reproduction Update 20 517. (doi:10.1093/humupd/dmu006)

Schäfers M \& Sorkin L 2008 Effect of cytokines on neuronal excitability. Neuroscience Letters 437 188-193. (doi:10.1016/j.neulet.2008.03.052)

Schröder A, Pandita RK, Hedlund P, Warner M, Gustafsson JA \& Andersson KE 2003 Oestrogen receptor subtypes and afferent signaling in the bladder. Journal of Urology 170 1013-1016. (doi:10.1097/01.ju. 0000080208.35782.ff)

Scotchie JG, Savaris RF, Martin CE \& Young SL 2014 Endocannabinoid regulation in human endometrium across the menstrual cycle. Reproductive Sciences 22 113-123. (doi:10.1177/1933719114533730)

Singh V, Ram M, Kandasamy K, Thangamalai R, Choudhary S, Dash JR, Kumar D, Parida S, Singh TU \& Mishra SK 2015 Molecular and functional characterization of TRPV4 channels in pregnant and nonpregnant mouse uterus. Life Sciences 122 51-58. (doi:10.1016/j.lfs. 2014.12.010)

Song N, Leng JH \& Lang JH 2012 [Expression of transient receptor potentials of vanilloid subtype 1 and pain in endometriosis]. Zhonghua Fu Chan Ke Za Zhi 47 333-336.

Southall MD, Tao L, Lera SG, Yong P, Grant DN \& Jeffrey BT 2003 Activation of epidermal vanilloid receptor-1 induces release of proinflammatory mediators in human keratinocytes. Journal of Pharmacology and Experimental Therapeutics 304 217-222. (doi:10.1124/ jpet.102.040675)

Srisuparp S, Strakova Z \& Fazlebas AT 2001 The role of chorionic gonadotropin (CG) in blastocyst implantation. Archives of Medical Research 32 627-634. (doi:10.1016/S0188-4409(01)00330-7)

Sun B, Nishihira J, Yoshiki T, Kondo M, Sato Y, Sasaki F \& Todo S 2005 Macrophage migration inhibitory factor promotes tumor invasion and metastasis via the rho-dependent pathway. Clinical Cancer Research 11 1050-1058.

Suzuki H, Kanagawa H \& Nishihira J 1996 Evidence for the presence of macrophage migration inhibitory factor in murine reproductive organs and early embryos. Immunology Letters 51 141-147. (doi:10.1016/01652478(96)02543-6)

Szallasi A, Cortright DD, Blum CA \& Eid SR 2007 The vanilloid receptor TRPV1: 10 years from channel cloning to antagonist proof-of-concept. Nature Reviews. Drug Discovery 6 357-373. (doi:10.1038/nrd2280)

Szoke E, Borzsei R, Toth DM, Lengl O, Helyes Zs, Sandor Z \& Szolcsanyi J 2010 Effect of lipid raft disruption on TRPV1 receptor activation of trigeminal sensory neurons and transfected cell line. European Journal of Pharmacology 628 67-74. (doi:10.1016/j.ejphar.2009.11.052)

Szolcsanyi J 1988 Antidromic vasodilatation and neurogenic inflammation. Agents and Actions 23 4-11. (doi:10.1007/BF01967170)

Telfer JF, Irvine GA, Kohnen G, Campbell S \& Cameron LT 1997 Expression of endothelial and inducible nitric oxide synthase in non-pregnant and decidualized human endometrium. Molecular Human Reproduction 3 69-75. (doi:10.1093/molehr/3.1.69)

Thippeswamy T 2006 Nitric oxide, a biological double-faced janus - is this good or bad? Histology and Histopathology 21 445-458.

Vivat V, Cohen-Tannoudji J, Revelli JP, Muzzin P, Giacobino JP, Maltier JP \& Legrand C 1992 Progesterone transcriptionally regulates the $\beta 2$-adrenergic receptor gene in pregnant rat myometrium. Journal of Biological Chemistry 267 7975-7978.

Wira CR, Fahey JV, Ghosh M, Patel MV, Hickey DK \& Ochiel DO 2010 Sex hormone regulation of innate immunity in the female reproductive tract: the role of epithelial cells in balancing reproductive potential with protection against sexually transmitted pathogens. American 
Journal of Reproductive Immunology 63 544-565. (doi:10.1111/j.16000897.2010.00842.x)

von Wolff M, Thaler CJ, Strowitzki T, Broome J, Stolz W \& Tabibzadeh S 2000 Regulated expression of cytokines in human endometrium throughout the menstrual cycle: dysregulation in habitual abortion. Molecular Human Reproduction 6 627-634. (doi:10.1093/ molehr/6.7.627)

Wu YW, Bi YP, Kou XX, Xu W, Ma LQ, Wang KW, Gan YH, Ma XC, Wu YW, Bi YP et al. 2010 17- $\beta$-oestradiol enhanced allodynia of inflammatory temporomandibular joint through up-regulation of hippocampal TRPV1 in ovariectomized rats. Journal of Neuroscience 30 8710-8719. (doi:10.1523/JNEUROSCI.6323-09.2010)
Wu YW, Hao T, Kou XX, Gan YH \& Ma XC 2015 Synovial TRPV1 is upregulated by 17- $\beta$-estradiol and involved in allodynia of inflamed temporomandibular joints in female rats. Archives of Oral Biology 60 1310-1318. (doi:10.1016/j.archoralbio.2015.05.011)

Xie Z \& Cai T $2003 \mathrm{Na}^{+}-\mathrm{K}^{+}$-ATPase-mediated signal transduction: from protein interaction to cellular function. Molecular Interventions $\mathbf{3}$ 157-168. (doi:10.1124/mi.3.3.157)

Yang Y, Degranpre P, Kharfi A \& Akoum A 2000 Identification of macrophage migration inhibitory factor as a potent endothelial cell growth-promoting agent released by ectopic human cells. Journal of Clinical Endocrinology and Metabolism 85 4721-4727. (doi:10.1210/ jcem.85.12.7003)

Received in final form 3 December 2015

Accepted 4 December 2015

Accepted Preprint published online 7 December 2015
Published by Bioscientifica Ltd. 